DEMOGRAPHIC RESEARCH

VOLUME 43, ARTICLE 33, PAGES 993-1008

PUBLISHED 29 SEPTEMBER 2020

https://www.demographic-research.org/Volumes/Vol43/33/

DOI: 10.4054/DemRes.2020.43.33

Descriptive Finding

The turnaround in internal migration between

East and West Germany over the period 1991

to 2018

Nico Stawarz

Nikola Sander

Harun Sulak

Matthias Rosenbaum-Feldbrügge

(C) 2020 Stawarz, Sander, Sulak \& Rosenbaum-Feldbrügge.

This open-access work is published under the terms of the Creative Commons Attribution 3.0 Germany (CC BY 3.0 DE), which permits use, reproduction, and distribution in any medium, provided the original author(s) and source are given credit.

See https://creativecommons.org/licenses/by/3.0/de/legalcode. 


\section{Contents}

1 Introduction $\quad 994$

2 Data and methods 995

3 Internal migration between East and West Germany 995

$3.1 \quad$ General findings 995

3.2 Differences by age 999

3.3 Differences by sex 1001

4 Discussion 1003

$\begin{array}{ll}\text { References } & 1005\end{array}$ 


\title{
The turnaround in internal migration between East and West Germany over the period 1991 to 2018
}

\author{
Nico Stawarz ${ }^{1}$ \\ Nikola Sander ${ }^{1}$ \\ Harun Sulak ${ }^{1}$ \\ Matthias Rosenbaum-Feldbrügge ${ }^{1}$
}

\begin{abstract}
BACKGROUND

After losing a population of more than 1.2 million through migration to the West, in 2017 East Germany recorded net internal migration gains for the very first time since reunification.
\end{abstract}

\section{OBJECTIVE}

In consideration of this trend reversal, we investigate internal migration patterns between East and West Germany since reunification and discuss their consequences for population dynamics.

\section{METHODS}

We use annual inter-county migration flows for the period 1991 to 2018 to calculate the yearly total number of registered moves and internal migration rates differentiated by citizenship, age, and sex.

\section{RESULTS}

East Germany currently experiences small net population gains through internal migration among almost all age groups and noticeable net population losses only among labor market entrants (25-29 year olds). In addition, the results show that men have dominated West-East migration throughout the entire study period and East-West migration since about 2008.

\section{CONCLUSIONS}

Internal migration between East and West Germany has changed significantly since reunification. The continuing population losses among labor market entrants reveal that the West German labor market is still more attractive for young adults. The sex

\footnotetext{
${ }^{1}$ Federal Institute for Population Research, Wiesbaden, Germany.

Corresponding author Nico Stawarz, Email: nico.stawarz@bib.bund.de.
} 
differences in migration propensities show that the shortages of women in many rural regions of East Germany cannot be solely explained by exceeding female East-West migration.

\section{CONTRIBUTION}

In 2017, East Germany experienced population gains thanks to internal migration for the first time since reunification. We provide scientific evidence to place the current migration trend reversal into context and highlight the selective nature of migration flows between East and West Germany.

\section{Introduction}

For the last 30 years, internal migration in Germany has been commonly associated with substantial net migration losses of the East to the West (Federal Statistical Office Germany and WZB Berlin Social Science Center 2018: 21ff.; Geißler 2014: 52ff.; Heiland 2004; Kempe, Schneider, and Hardt 2001). Since reunification in 1990, the East German states of the former German Democratic Republic experienced a net population loss of 1.2 million people to the West German states through internal migration. These systematic migration flows to the West are typically attributed to inferior employment conditions in East Germany reflected by fewer job opportunities, higher unemployment rates, and lower wages (Alecke, Mitze, and Untiedt 2009; Büchel and Schwarze 1994; Burda 1993; Burda and Hunt 2001; Glorius 2010). As a consequence of selective outmigration, many rural regions in the former East German states are confronted with accelerated population ageing, population decline, and shortages of women on the regional partner markets (Eckhard and Stauder 2018; FuchsSchündeln and Schündeln 2009; Kühntopf and Stedfeld 2012; Mai 2006; Werding 2002).

In 2017, however, the long-term trend reversed and East Germany recorded an overall net migration gain for the first time since the Fall of the Wall in 1989/1990 (Stawarz and Rosenbaum-Feldbrügge 2020). In this descriptive paper, we explore the underlying dimensions of this trend reversal and focus specifically on the role differences in migration behavior by age and sex. 


\section{Data and methods}

We use time-series data of annual inter-county migration flows derived from the Federal Statistical Office Germany and the Statistical Offices of the Länder for the period of 1991-2018. The data have been harmonised for boundary changes by the Federal Institute for Research on Building, Urban Affairs and Spatial Development (BBSR 2010). These data capture all permanent and officially registered changes of residence across municipal boundaries and contain information about the yearly total number of moves taking place between all German counties within a one-year period (Sander 2014). The data are disaggregated by sex, citizenship (German and nonGerman), and age group (under 18, 18-24, 25-29, 30-49, 50-64, and 65 and over).

In our analysis, we aggregate the migration flows from the county-level to the three regions East Germany, West Germany, and Berlin as the capital city. Berlin used to be divided between the Federal Republic of Germany and the German Democratic Republic, but today's official statistics do not differentiate between the former Eastern and Western parts of Berlin. Therefore, it is not possible to classify internal migration moves involving Berlin according to the East-West-dichotomy. We therefore treat Berlin as a separate region.

We calculate the total number of moves between these regions per year. Given that the absolute numbers of annual moves are a function of the age-sex structure of the population in the origin region that is at risk of moving, we calculate migration rates to take the underlying structure of the population into account. We express the rate as a percentage of the mid-year population residing in the sending region (Bell et al. 2002). In the following section, we report total numbers of moves as well as rates of migration between East and West Germany, while also considering the role of Berlin.

\section{Internal migration between East and West Germany}

\subsection{General findings}

We first look at how migration between the East and the West evolved over time in terms of total numbers. Figure 1 shows the number of moves between East and West Germany for the period 1991 to 2018, as well as the total number of moves by citizenship (foreign/native). Internal migration flows from East to West Germany varied strongly over time (Figure 1a). Migration to West Germany peaked in 1991 at around 230,000 moves and again in 2001 at more than 190,000 moves. The peak in 2001 may be related to the weak economic development and a further rise in the unemployment rate that characterized East Germany in the early 2000s (Krause 2019). From 2001 to 
2018, the total number of moves declined consistently to less than half as economic conditions improved in the East. The number of persons moving from West to East Germany, in contrast, was remarkably stable at around 80,000 to 90,000 moves per year during the entire period. This is especially true when we look at the trend for German citizens only (see Figure 1b). In sum, internal migration flows since reunification contributed to a net population loss of more than 1.2 million persons for East Germany, which corresponds to an average loss of about 43,000 individuals per year. Between 2008 and 2016, however, the net loss decreased to 18,000 persons per year. In 2017 and 2018 we observe for the first time since reunification small net gains for East Germany of about 4,000 and 650 persons, respectively. A separate analysis for Berlin (Figure 2) reveals that the former divided city experienced substantial net population losses to East Germany in the 1990s, the beginning of the 2000s, and since about 2011. This is most likely attributed to individuals leaving the city of Berlin to move to its hinterland that extends into the East German county of Brandenburg. Since the mid-2000s, Berlin has become an attractive destination for individuals from West Germany, resulting in consistent net gains for Berlin with the West through internal migration.

Comparing the flows of German citizens and foreigners (Figure 1b and 1c) shows that the high rate of international immigration to Germany between 2014 and 2016 somewhat bias the recent trend in East-West internal migration. The small peak in internal migration flows in 2016 depicted in Figure 1a is largely driven by high numbers of refugees, whose redistribution across Germany was reflected as internal migration, and who tended to move from East to West Germany in 2016. When only German citizens are taken into account, East Germany has already experienced constant net population gains since 2014. The net population gains among German internal migrants in 2017 and 2018 correspond to around 8,100 and 7,800. The trend of movements from West to East Germany is therefore largely driven by German citizens. The East German federal states of Brandenburg (which surrounds the city of Berlin), Mecklenburg-Vorpommern, and Saxony benefited most from the recent net migration gains, whereas Thuringia and Saxony-Anhalt still experience net population losses.

The internal migration rates presented in Table 1 for selected years confirm that internal migration from East to West Germany peaked in 1991 and again in 2001, and decreased almost linearly from 2002 onwards. In constrast, migration from West to East Germany remained more or less stable over the entire study period. This general trend, however, does not hold for internal migration among foreigners, which increased since 2015 as a result of high levels of immigration and subsequent redistribution of refugees from the arrival centers. The internal migration rates from East to West are higher than the rates for migration from West to East because the size of the population is much larger in the West. 
Figure 1: Internal migration between East and West Germany (without Berlin)

(a) Total

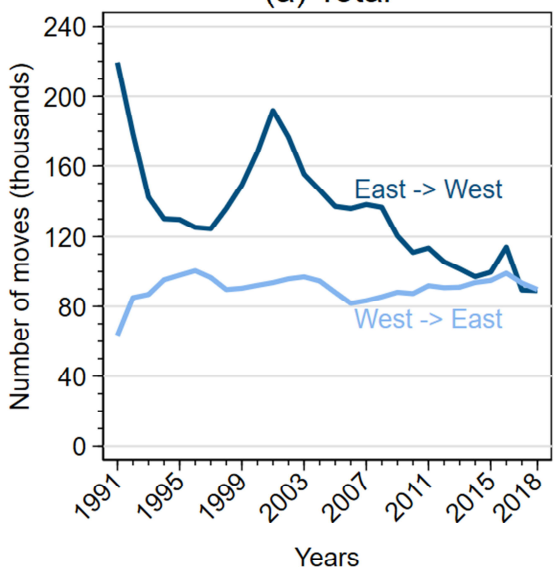

(c) Foreigners

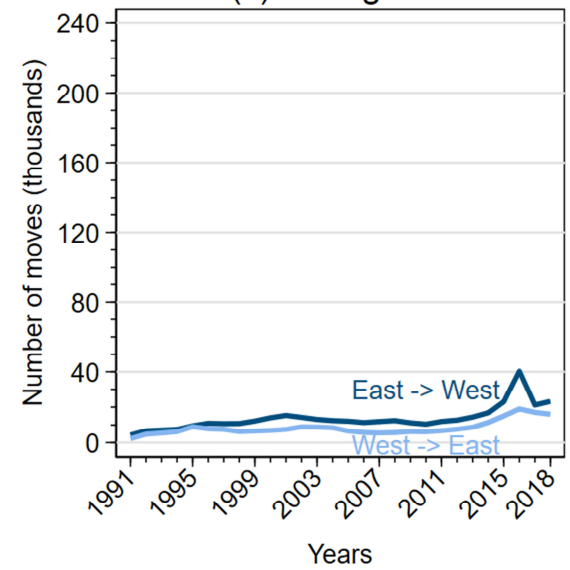

(b) Germans

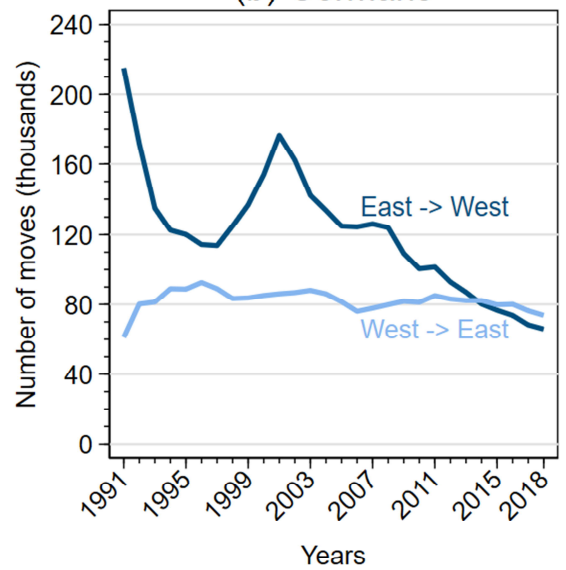

Source: Federal Statistical Office Germany and the Statistical Offices of the Länder, Spatial Monitoring of the BBSR, own calculations. 
Figure 2: Internal migration between Berlin and East and West Germany
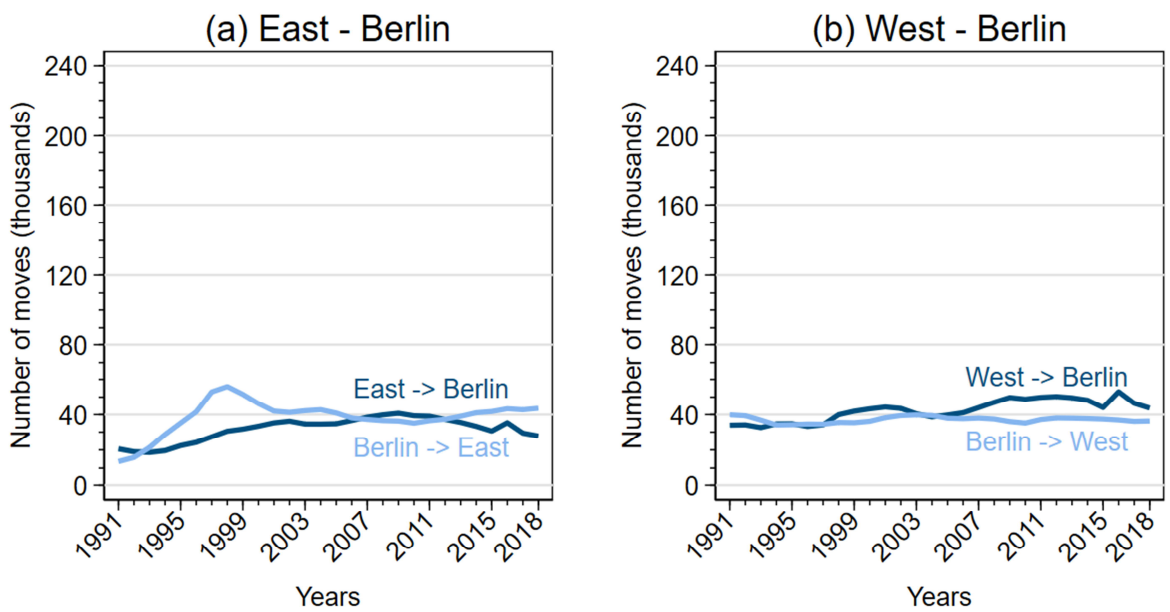

Source: Federal Statistical Office Germany and the Statistical Offices of the Länder, Spatial Monitoring of the BBSR, own calculations.

Table 1: Internal migration rates between East and West Germany (without Berlin), expressed as a percentage of the mid-year population residing in the sending region

\begin{tabular}{llccccc}
\hline & Total & $\begin{array}{c}\text { East }->\text { West } \\
\text { Germans }\end{array}$ & Foreigners & Total & $\begin{array}{c}\text { West }>\text { East } \\
\text { Germans }\end{array}$ & Foreigners \\
\hline 1991 & 1.50 & 1.48 & 3.85 & 0.10 & 0.11 & 0.04 \\
1993 & 0.99 & 0.95 & 4.12 & 0.14 & 0.14 & 0.09 \\
1995 & 0.91 & 0.86 & 4.19 & 0.15 & 0.15 & 0.14 \\
1997 & 0.88 & 0.82 & 4.02 & 0.15 & 0.15 & 0.11 \\
1999 & 1.07 & 1.00 & 4.42 & 0.14 & 0.14 & 0.10 \\
2001 & 1.39 & 1.31 & 5.20 & 0.14 & 0.15 & 0.11 \\
2003 & 1.14 & 1.07 & 4.10 & 0.15 & 0.15 & 0.13 \\
2005 & 1.02 & 0.96 & 3.79 & 0.13 & 0.14 & 0.10 \\
2007 & 1.05 & 0.98 & 3.76 & 0.13 & 0.13 & 0.09 \\
2009 & 0.93 & 0.86 & 3.64 & 0.13 & 0.14 & 0.10 \\
2011 & 0.89 & 0.82 & 4.41 & 0.14 & 0.14 & 0.11 \\
2013 & 0.81 & 0.71 & 5.38 & 0.14 & 0.14 & 0.14 \\
2015 & 0.79 & 0.63 & 5.65 & 0.14 & 0.14 & 0.21 \\
2016 & 0.91 & 0.61 & 8.05 & 0.15 & 0.14 & 0.14 \\
2017 & 0.71 & 0.57 & 3.89 & 0.14 & 0.13 & 0.21 \\
2018 & 0.71 & 0.55 & 3.97 & 0.13 & 0.13 & 0.19 \\
\hline
\end{tabular}

Source: Federal Statistical Office Germany and the Statistical Offices of the Länder, Spatial Monitoring of the BBSR, own calculations. 


\subsection{Differences by age}

Figure 3 highlights strong differences by age in internal migration patterns over the whole period. The results also show that the recently observed trend reversal is to a large degree driven by a strong decline in East-West migration among 18 to 24 year olds over time. Whereas more than 60,000 individuals aged 18 to 24 years moved from East to West Germany in the peak year of 2001, this number decreased to around 20,000 in 2018. In a similar fashion, steady declines in migration among families (ages 0-17 and 30-49 years) from East to West Germany since 2001 contributed considerably to East Germany's recent net population gains. Remarkably, the total number of individuals aged 30 to 49 who moved from West to East Germany increased from around 22,000 in 2006 to more than 30,000 in 2018. No other age group reveals similar increases in migration from West to East Germany in these years. Migration of those entering the labor market (ages 25-29 years) followed a different pattern, with EastWest migration starting to decline only in 2009 and remaining above the level of WestEast migration throughout the entire period. This suggests that some labor market differences still exist between East and West Germany, which are likely to influence internal migration patterns at the labor force entry stage even 30 years after German reunification. Migration among those aged 50 to 64 and those aged 65 and over was very low in intensity (less than 10,000 moves per year) and remained largely stable over time. What is worth noting, however, is the slight increase in West-East migration among 50 to 64 year olds, which may indicate an increase in return migration to the East among those who moved to the West upon reunification.

Internal migration rates for specific years and for selected age groups are presented in Table 2. In general, the internal migration rates reproduce the trends for the specific age groups identified in Figure 3 very well. Internal migration from East to West Germany peaked in 1991 and 2001 among the age groups 18 to 24,25 to 29 , and 30 to 49 years, and has been decreasing since the beginning of the century. In general, internal migration rates are by far the highest among the 18 to 24 year olds. It is striking that in 1991 and 2001 around $5 \%$ of the individuals aged 18 to 24 living in East Germany decided to move to the West. In line with Figure 3, internal migration from West to East generally reveals much less volatility and confirms that the recent increase in the number of moves to East Germany is driven by migration among the 30 to 49 year olds. 
Figure 3: Internal migration between East and West Germany by different age groups (without Berlin)

(a) under 18

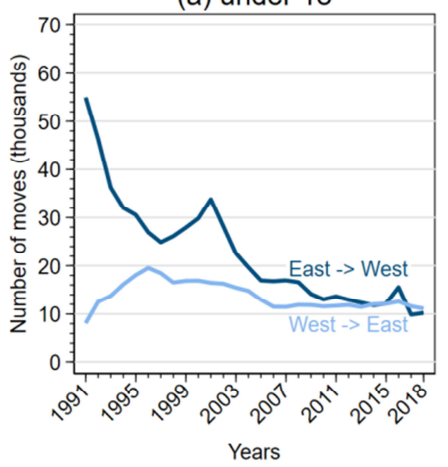

(c) $25-29$

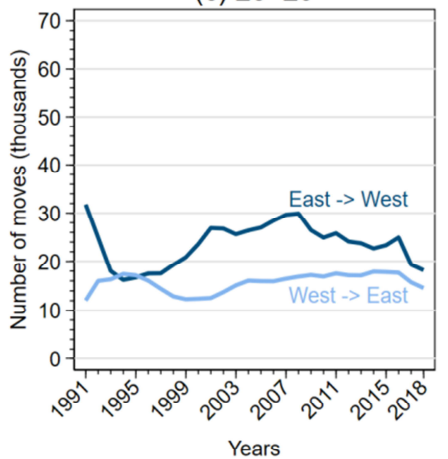

(e) $50-64$

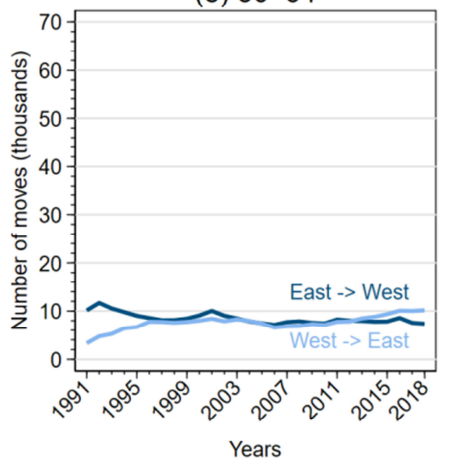

(b) 18-24

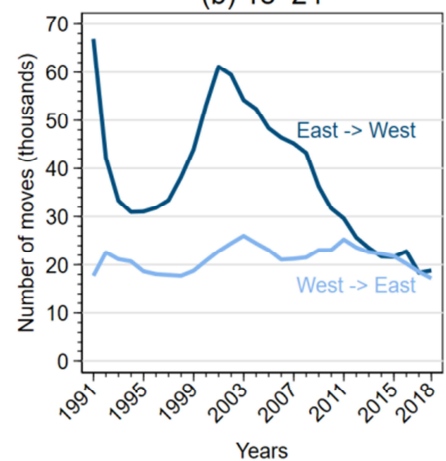

(d) $30-49$

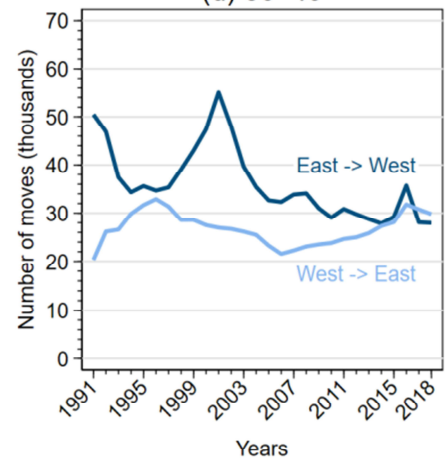

(f) over 64

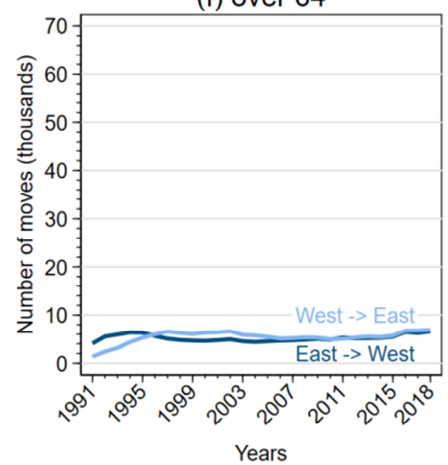

Source: Federal Statistical Office Germany and the Statistical Offices of the Länder, Spatial Monitoring of the BBSR, own calculations. 
Table 2: Internal migration rates between East and West Germany (without Berlin) for selected age groups, expressed as a percentage of the midyear population in the given age group residing in the sending region

\begin{tabular}{lcccccc}
\hline & \multicolumn{3}{c}{ East $\rightarrow$ West } & & & West $>$ East \\
& $18-24$ & $25-29$ & $30-49$ & $18-24$ & $25-29$ & $30-49$ \\
\hline 1991 & 5.12 & 2.74 & 1.27 & 0.28 & 0.22 & 0.12 \\
1993 & 2.86 & 1.68 & 0.93 & 0.36 & 0.29 & 0.15 \\
1995 & 2.78 & 1.68 & 0.85 & 0.36 & 0.31 & 0.17 \\
1997 & 2.95 & 1.89 & 0.81 & 0.37 & 0.29 & 0.16 \\
1999 & 3.62 & 2.54 & 0.97 & 0.38 & 0.28 & 0.14 \\
2001 & 4.81 & 3.75 & 1.27 & 0.45 & 0.32 & 0.13 \\
2003 & 4.26 & 3.62 & 0.95 & 0.51 & 0.40 & 0.13 \\
2005 & 3.85 & 3.54 & 0.82 & 0.44 & 0.42 & 0.11 \\
2007 & 3.71 & 3.70 & 0.89 & 0.40 & 0.42 & 0.11 \\
2009 & 3.22 & 3.33 & 0.85 & 0.43 & 0.44 & 0.12 \\
2011 & 3.15 & 3.31 & 0.90 & 0.47 & 0.45 & 0.13 \\
2013 & 3.10 & 3.07 & 0.89 & 0.43 & 0.43 & 0.14 \\
2015 & 3.28 & 2.98 & 0.93 & 0.41 & 0.42 & 0.16 \\
2016 & 3.51 & 3.28 & 1.15 & 0.37 & 0.41 & 0.18 \\
2017 & 2.80 & 2.76 & 0.91 & 0.34 & 0.36 & 0.18 \\
2018 & 2.79 & 2.89 & 0.91 & 0.32 & 0.34 & 0.18 \\
\hline
\end{tabular}

Source: Federal Statistical Office Germany and the Statistical Offices of the Länder, Spatial Monitoring of the BBSR, own calculations.

\subsection{Differences by sex}

We now turn to sex differences in internal migration flows between East and West Germany. Figure 4 shows the total numbers of men and women moving from East to West and from West to East, respectively. Before 2008, the sex differences in EastWest migration were negligible. The total number of women migrating from East to West was only slightly higher than the number of men in the early 1990s. After 2008, however, the migration flow from East to West has been dominated by males. An additional analysis (not reported here) reveals that the excess of males moving from East to West is mainly a result of the steep decline in moves among young females aged 18 to 24 . The West-East migration, in contrast, was dominated by males throughout the entire period, which was particularly pronounced in the decade after reunification.

Comparing the rates of internal migration for men and women reveals a similar picture (see Table 3). Since about 2007, there have been higher internal migration rates for men compared to women migrating from East to West. Eastward migration, in contrast, remained stable over time, with men being much more likely to move to the East in the 1990s. Interestingly, Table 3 indicates that female migration rates from East to West Germany between 1992 and 1995 were not higher than migration rates of 
males. Accordingly, during the 1990s women living in East Germany were not more likely to move to West Germany than men.

Figure 4: Internal migration flows between East and West Germany by sex (without Berlin)

(a) East -> West

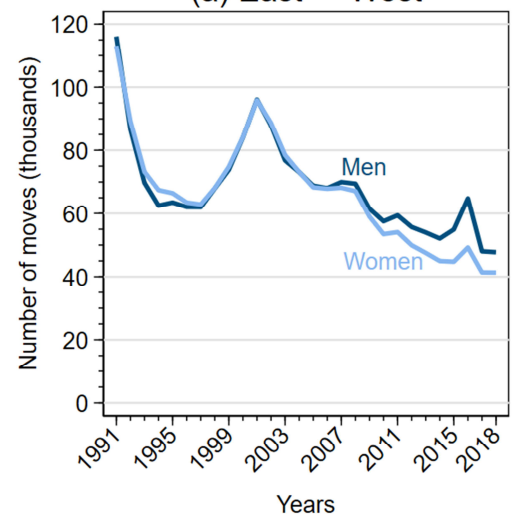

(b) West -> East

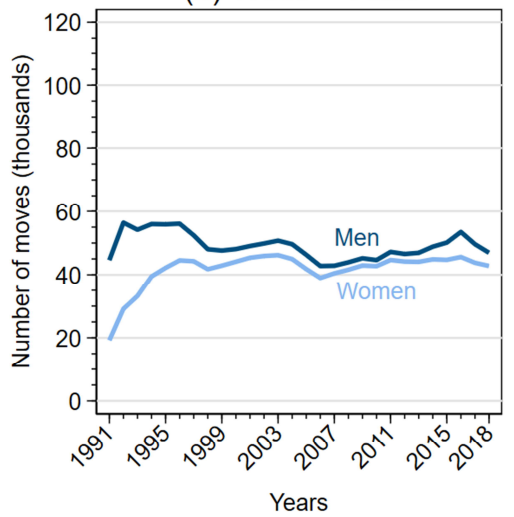

Source: Federal Statistical Office Germany and the Statistical Offices of the Länder, Spatial Monitoring of the BBSR, own calculations.

Table 3: Internal migration rates between East and West Germany by sex (without Berlin), expressed as a percentage of the sex-specific midyear population residing in the sending region

\begin{tabular}{lcccc}
\hline & East -> West & & West -> East \\
& Men & Women & Men & Women \\
\hline 1991 & 1.66 & 1.48 & 0.15 & 0.06 \\
1993 & 1.01 & 0.98 & 0.18 & 0.10 \\
1995 & 0.92 & 0.91 & 0.18 & 0.13 \\
1997 & 0.90 & 0.87 & 0.17 & 0.13 \\
1999 & 1.08 & 1.04 & 0.15 & 0.13 \\
2001 & 1.43 & 1.36 & 0.15 & 0.14 \\
2003 & 1.15 & 1.13 & 0.16 & 0.14 \\
2005 & 1.05 & 1.00 & 0.14 & 0.12 \\
2007 & 1.08 & 1.02 & 0.13 & 0.12 \\
2009 & 0.96 & 0.89 & 0.14 & 0.13 \\
2011 & 0.95 & 0.84 & 0.15 & 0.13 \\
2013 & 0.88 & 0.75 & 0.15 & 0.13 \\
2015 & 0.89 & 0.70 & 0.16 & 0.13 \\
2016 & 1.04 & 0.77 & 0.16 & 0.14 \\
2017 & 0.77 & 0.65 & 0.15 & 0.13 \\
2018 & 0.77 & 0.65 & 0.14 & 0.13 \\
\hline
\end{tabular}

Source: Federal Statistical Office Germany and the Statistical Offices of the Länder, Spatial Monitoring of the BBSR, own calculations. 


\section{Discussion}

The aim of this paper was to highlight the recent shift in internal migration flows between East and West Germany and explore underlying age-sex patterns. We used internal migration data from the Federal Statistical Office Germany and the Statistical Offices of the Länder for a period of 28 years (1991 to 2018) since German reunification, and analysed the changes in migration flows disaggregated by age and sex.

Our results show that the total number of moves and migration rates from East to West Germany declined constantly since the beginning of the 2000s, whereas the number of moves from West to East Germany remained more or less stable throughout the entire period. As a result of this shift, East Germany experienced net population gains for the first time since reunification in 2017 and 2018. When only taking German citizens into account, West-East flows have exceeded East-West migration already since 2014. With regard to age differences, our findings reveal that East Germany recently experienced population gains among almost all ages groups. Noticeable net losses for the East are only recorded for those aged 25 to 29 years. Concerning sex differences, male migration from West to East Germany exceeded female migration throughout the entire period and was particularly pronounced in the 1990s. In contrast to previous studies, we found little evidence for a female-dominated East-West migration regime. In fact, we found hardly any sex differences in East-West migration between 1991 and 2008. Thereafter, men recorded higher migration numbers and internal migration rates than women.

Particularly the migration patterns of educational migrants (aged 18 to 24) and families (children below age 18 and 30 to 49 year olds) contributed to East Germany experiencing small population gains in 2017 and 2018. Migration flows to the West also decreased for labor market entrants aged 25 to 29, but East Germany still faces relevant losses through migration among this age group. Even though East Germany experienced an economic revival in the recent decades (Arbeitskreis 'Volkswirtschaftliche Gesamtrechnungen der Länder' 2019; BBSR 2016; Bundesagentur für Arbeit 2019; Krause 2019; Milbert and Sturm 2016), the findings indicate that the labor market situation in West Germany continues to be more favorable and attractive for young people at the beginning of their career. Accordingly, the ongoing efforts to improve the labor market situation in East Germany should be maintained to facilitate equivalent employment and living conditions in East and West.

Previous work shows that rural areas in East Germany have the strongest shortage of young women in Europe (Leibert 2016), which has been attributed to high levels of female outmigration from East to West Germany (Kröhnert and Vollmer 2012). Our findings, however, reveal that there were hardly any sex differences in East-West 
migration in the two decades after reunification and that men in East Germany have even been more likely to move to the West than women from 2008 onwards. Our results thus suggest that the unbalanced sex-ratios in rural areas of East Germany are caused by higher levels of male migration from West to the East, rather than by higher levels of female migration from East to West. Shortages of young women in rural areas can also be attributed to young females being more likely to move to urban areas for educational and job-related reasons than their male counterparts of the same ages (Eckhard and Stauder 2018). This phenomenon, however, is not only restricted to East Germany and also affects rural regions in West Germany which are increasingly confronted with shortages of young women as well.

In conclusion, this paper contributes to our understanding of the tournaround in internal migration between East and West Germany over the period 1991 to 2018 . We shed light on the age-sex patterns that underlie the trend towards positive net migration for East Germany that occurred in 2017 for the first time since reunification. However, current population gains experienced by East Germany are still insignificant compared to the accumulated past population losses of around 1.2 million individuals. Given that East Germany is characterized by negative natural population growth and much smaller gains through net international migration, internal migration is the key factor shaping population change in the East (Stawarz and Sander 2020). Moreover, the turnaround in migration flows between East and West Germany has not yet occurred in all East German states. While many counties in Brandenburg that are located within communting distance to Berlin record strong population gains, other more remotely located counties close to the Polish border still face population losses. Furthermore, the East still records net migration losses of labor market entrants (ages 25-29) to the West. As a consequence, the trend reversal in internal migration observed in 2017 and 2018 can by no means be seen as a turning point in levelling out the structural disadvantages associated with population ageing, population decline, and unbalanced sex-ratios that are prevalent in many rural areas of East Germany. 


\section{References}

Alecke, B., Mitze, T., and Untiedt, G. (2009). Internal migration, regional labour market dynamics and implications for German East-West disparities. Results from a Panel VAR. Ruhr Economic Papers 9: 1-54. doi:10.2139/ssrn.1374981.

Arbeitskreis 'Volkswirtschaftliche Gesamtrechnungen der Länder' (2019). Bruttoinlandsprodukt, Bruttowertschöpfung in den Ländern der Bundesrepublik Deutschland 1991 bis 2018. Stuttgart: Statistisches Bundesamt (Destatis).

BBSR (2010). Gebietsreformen - politische Entscheidungen und Folgen für die Statistik (BBSR-Berichte KOMPAKT). Bonn: BBSR.

BBSR (2016). Neue Ansichten auf die Wohnungsmieten. Bonn: BBSR.

Bell, M., Blake, M., Boyle, P., Duke-Williams, O., Rees, P., Stillwell, J., and Hugo, G. (2002). Cross-national comparison of internal migration: Issues and measures. Journal of the Royal Statistical Society: Series A 165(3): 435-464. doi:10.1111/1467-985X.00247.

Büchel, F. and Schwarze, J. (1994). Die Migration von Ost- nach Westdeutschland Absicht und Realisierung. Mitteilungen aus der Arbeitsmarkt- und Berufsforschung 27(1): 43-52.

Bundesagentur für Arbeit (2019). Arbeitslosigkeit im Zeitverlauf: Entwicklung der Arbeitslosenquote. Nürnberg: Bundesagentur für Arbeit.

Burda, M.C. (1993). The determinants of East-West German migration. Some first results. European Economic Review 37(2-3): 452-461. doi:10.1016/00142921(93)90034-8.

Burda, M.C. and Hunt, J. (2001). From reunification to economic integration: Productivity and the labour market in East Germany. Brooking Papers on Economic Activity 2: 1-92. doi:10.1353/eca.2001.0016.

Eckhard, J. and Stauder, J. (2018). Migration and the partner market: How genderselective relocations affect regional mating chances in Germany. European Journal of Population 34: 59-86. doi:10.1007/s10680-017-9422-8.

Federal Statistical Office Germany and WZB Berlin Social Science Center (eds.) (2018). Datenreport 2018. Ein Sozialbericht für die Bundesrepublik Deutschland. Bonn: Bundeszentrale für politische Bildung. 
Fuchs-Schündeln, N. and Schündeln, M. (2009). Who stays, who goes, who returns? East-West migration within Germany since reunification. Economics of Transition 17(4): 703-738. doi:10.1111/j.1468-0351.2009.00373.x.

Geißler, R. (2014). Die Sozialstruktur Deutschlands. 7th ed. Wiesbaden: VS. doi:10.1007/978-3-531-19151-5.

Glorius, B. (2010). Go west : Internal migration in Germany after reunification. Belgeo 3: 281-292. doi:10.4000/belgeo.6470.

Heiland, F. (2004). Trends in East-West German migration from 1989 to 2002. Demographic Research 11(7): 173-194. doi:10.4054/DemRes.2004.11.7.

Kempe, W., Schneider, H., and Hardt, G. (2001). Ost-West-Wanderung junger Menschen Ausdruck für allgemeinen Anstieg der Mobilität. Wirtschaft im Wandel 7(4): 67-74.

Krause, P. (2019). 30 Jahre seit dem Mauerfall: Fortschritte und Defizite bei der Angleichung der Lebens-verhältnisse in Ost- und Westdeutschland. DIW Wochenbericht (45/2019): 828-838.

Kröhnert, S. and Vollmer, S. (2012). Gender-specific migration from eastern to western Germany: Where have all the young women gone? International Migration 50(5): 95-112. doi:10.1111/j.1468-2435.2012.00750.x.

Kühntopf, S. and Stedfeld, S. (2012). Wenige junge Frauen im ländlichen Raum: Ursachen und Folgen der selektiven Abwanderung in Ostdeutschland. Wiesbaden: Bundesinstitut für Bevölkerungswissenschaften.

Leibert, T. (2016). She leaves, he stays? Sex-selective migration in rural East Germany. Journal of Rural Studies 43: 267-279. doi:10.1016/j.jrurstud.2015.06.004.

Mai, R. (2006). Die alterselektive Abwanderung aus Ostdeutschland. Raumforschung und Raumordnung 64(5): 355-369. doi:10.1007/BF03184531.

Milbert, A. and Sturm, G. (2016). Binnenwanderungen in Deutschland zwischen 1975 und 2013. Informationen zur Raumentwicklung 2: 121-144.

Sander, N. (2014). Internal migration in Germany, 1995-2010: New insights into eastwest migration and re-urbanisation. Comparative Population Studies 39(2): 217246.

Stawarz, N. and Rosenbaum-Feldbrügge, M. (2020). Binnenwanderung in Deutschland seit 1991: Aktuelle Analysen und Befunde. Bevölkerungsforschung Aktuell 41(2): 3-7. 
Stawarz, N. and Sander, N. (2020). The impact of internal migration on the spatial distribution of population in Germany over the period 1991-2017. Comparative Population Studies 44: 291-316.

Werding, M. (2002). Ost-West-Wanderungen in Deutschland: Die Jungen gehen - Alte kommen. ifo Schnelldienst 55(4): 44-45. 
Stawarz et al.: The turnaround in internal migration between East and West Germany from 1991 to 2018 